\title{
Polish Jewish Literature: A Brief History, Theoretical Framework, and a Teaching Example
}

"There is no Polish history without the Jews, and there is no Jewish history without Poland." Such are the words of the prominent historian Jacob Goldberg, who was born in Łódź, survived the Buchenwald concentration camp, and immigrated to Israel in 1968, where he became a professor at the Hebrew University of Jerusalem. Since the Middle Ages, a shared past and historical experience has linked Polish and Jewish literatures inextricably, as manifested in its Polish denomination "literatura polsko-żydowska". This term denotes, I would argue, Jewish literatures (in the plural) written in Hebrew, Yiddish, and Polish in the territories of Poland, including, but not limited to, those landscapes historically Polish.

This article consists of two major parts and a teaching example: the first part briefly outlines the history of Polish Jewish literatures, while the second part discusses two essays by Władysław Panas (1947-2005), a leading Polish literary scholar whose essays The Writing and the Wound: On Polish-Jewish Literature (1987) and The Eye of the Tzaddik (1999) reflect the methodological complexity inherent in thinking about Polish Jewish literatures. Finally, I present an exemplary program of a seminar course I have developed for students of the Master's degree program in "East European Cultural Studies" at Potsdam University in winter term 2016/2017, most of whom do not know the source languages.

\section{History, definitions, and fields of study}

The long history of Polish Jews began with the rule of the Piast dynasty in the tenth century. It started with the arrival of the first Jews travelling along trade routes leading eastwards and intensified during the time of the crusades, which resulted in large waves of emigration by Jewish people banished from Western Europe.

A look into the medieval legend describing the arrival of Jewish emigrants in Poland underlines the special role that this country plays in Jewish thought and history more broadly. One of its versions can be found in the beginning of Das Buch von den polnischen Juden (The Book of the Polish Jews), edited by S. Y. Agnon and Ahron Eliasberg and co-authored by Martin Buber, among others. 
This extraordinary work was printed in Berlin (Jüdischer Verlag) in 1916 during the First World War at a time when the Polish state had not existed for more than 120 years following the Partitions of Poland, which began in 1772 and divided the country between the Habsburg Empire, the Kingdom of Prussia, and the Russian Empire. It was written in German in the tradition of the genre called 'Heimatbuch' (books about homelands, their history and regional traditions) by two authors who did not speak Polish with the aim of introducing the Polish Jewry to a German speaking audience.

In the medieval legend that Agnon retells at the beginning of this book, we read about banished Jews travelling from Western Europe eastwards who suddenly received a sign: a piece of paper fell from heaven, and on it were the words Gehet nach Polen, go to Poland! $(1916,3)$. On their way, they discovered a forest where a tractate of the Talmud was carved into every tree. This was the Kawczyn (now Kawęczyn) forest that led to Lublin (4). They decided to stay there also because they ascribed a special etymology to the name of the country. Poland, in Hebrew Polin, consists of two words po - lin, which means: rest here for the night (4).

The nature of the land is described as predestined for the Jews and filled with spirit, scripture, and languages. We can trace here the urge to charge a physical space with symbolic meaning: messianism played an important role in the thought of eastern European Jewry, and Poland became an important place in Judaism.

The long-lasting experience of a common history and shared space is certainly reflected in literary texts. There are many historical and literary studies that systematize this material (for example Żurek 2008, Ben-Zvi 2011, ProkopJaniec/Żurek 2011, Kołodziejska/Antosik-Piela 2017, 2018). In order to outline this vast area of study, several milestones in research will be briefly discussed in what follows.

The development of Jewish literature on the territory of the Polish-Lithuanian Commonwealth is associated with the Haskalah - the Jewish Enlightenment. During the time of the partitions of Poland, there were several leading thinkers writing in Hebrew who lived in Galicia or Podolia - including, among others, Menachem Mendel Lefin (1749-1826) and Josua Höschel Schorr (1818-1895), called the "Voltaire of Galicia." In this region, Hebrew was the dominant language of Jewish writings in the nineteenth century. Many Hebrew journals began to be published, including the weekly magazine Hacefira in Warsaw and the literary monthly Ha-Boker Or in Lwów, as well as an emerging body of Hebrew secular literature. At the same time, literary writing in Yiddish became more popular. This was mainly due to the limitations presented by Hebrew literature, which was read primarily by the intellectual elite. As a result, many writers 
began to produce works in Yiddish (for example Isaac Leib Peretz), and some others (such as Joseph Perl) who had previously written in Hebrew, also switched to their native language.

The first works written in Polish by Jews stem from the turn of the eighteenth century and are connected with the Frankists, a Jewish religious movement, centered on the leadership of the Jewish Messiah claimant Jacob Frank (1726-1791) (Maciejko 2011). The development of a tendency towards acculturation in Poland in the nineteenth century fostered the beginning of Jewish journalism and Jewish literatures in Polish. The heyday of Jewish Polish literature came in the interwar decades (1918-1939), when it became a distinct artistic and cultural phenomenon (Prokop-Janiec 2003, Molisak/Dąbrowski 2006). Its rise was influenced by the acculturation of Jewish communities and their linguistic Polonization. The high circulation of material published by Jewish presses in Polish contributed significantly to these processes. These presses published literary manifestos as well as discussions on the role of the Polish language in Jewish life, the nature of Polish Jewish literary works, and their place in the changing Jewish culture. Especially notable is the Trade Union of Jewish Writers and Journalists, which was founded in 1916, with its seat in Warsaw. It was also called the Union of Men of Letters (Yiddish: Literatn Farajn) and had an important voice in the literary society in Poland. Its members were men of letters who wrote in either Yiddish or Hebrew, as well as bilingual authors writing in Polish-Yiddish and Polish-Hebrew (Segałowicz 2001).

Polish Jewish literatures are the result of two cultures and of their merging into a new dynamic cultural sphere. Its complexity consists, according to Polish literary scholar Jacek Leociak, in "the consistent adoption of the stigma of the Jewish fate of exiles and entry in the space of the drama of existence torn, thrown, between (at least) two cultures and two languages. The decision to choose a language meets head on with the act of national self-identification" (Leociak 1995, 145). For some authors (such as Julian Tuwim or Antoni Słonimski), this was a decision to strongly identify with Polish cultural belonging and for others (such as Maurycy Szymel or Roman Brandstaetter), a decision to create Jewish literature in Polish. Both of these literary developments were part of a dynamic cultural process. For these writers, Polish was no longer an assimilation tool; it became a cultural medium that functioned as a bridge between two communities.

Polish Jewish literature has a heterogeneous character and is part of both multi-lingual Jewish writing and also Polish culture: literary works created by writers of Jewish belonging and addressed to a Polish audience are part of Polish national literature. In addition to the authors mentioned above, this circle includes, for example, Bolesław Leśmian, Bruno Jasieński, Jan Brzechwa, Jan Le- 
choń, Janusz Korczak, Tadeusz Peiper, Józef Wittlin, Julian Stryjkowski (Hutchens 2019), Adam Ważyk, Aleksander Wat, or the contemporary writer Henryk Grynberg (Polonsky/Adamczyk-Garbowska 2001). There were also many Polish Jewish female authors: inter alia Malwina Meyersonowa, Maria Blumberg, Lena Bandówna, Salomea Perl, Czesława Endelmanowa, and Aniela Korngutówna (Prokop-Janiec 2013, 140 -141). Literary scholars underscore that nineteenth-century Polish Jewish prose was "largely a domain of women" (ibid.). The female writers mentioned above chose prose genres more often than female authors writing in Yiddish and Hebrew, who tended to prefer poetry. Anita Norich explains this phenomenon as a result of the strong male story-telling tradition that was characteristic of these languages (Norich 1992, 12). In the beginning of the twentieth century, several Polish Jewish female poets became visible on the literary scene, such as Anda Eker and Debora Vogel, the latter one wrote in Polish and Yiddish.

The field of study generally called Polish Jewish literature addresses the major issues in defining this body of literature. In the following, I would like to highlight some of the problems and challenges its researchers have to deal with.

The first step is defining appropriate categories as a preliminary condition for the study of the complex phenomenon under discussion. It is difficult to specify exactly what Polish Jewish literature is. Jewish literature is defined in general as a phenomenon created in many languages in the context of different cultures of individual countries (Adamczyk-Garbowska 2004). Multilingualism is also its determinant in Poland (Prokop-Janiec 2002). Literary texts are written in Hebrew, Polish, and Yiddish, but also in Karaim, as is the case, for example, of the by Aleksander Mardkowicz. ${ }^{1}$ The criterion for ethnical belonging attributed to their authors is not always sufficient: scholars are often guided by thematic or biographical determinants, often referring to autobiographical sources - the statements of the writers about themselves (Molisak/Kołodziejska 2011).

Secondly, and as a consequence of the preceding assumption, problems arise concerning translation and reception. The point is that such diverse criteria also allow for the inclusion of translations in the textual corpus of Polish Jewish literature: these demonstrate a literary exchange between Poles and Jews. However, we are dealing here with a certain asymmetry that gives rise to separate studies. Within Poland, non-Jewish Polish writers of the Romantic or Positivist periods were interested in Jewish topics and placed Jewish protagonists in their texts as subjects of description, even as there were very few translations into Polish of works by actual Jewish authors writing in other languages. This

1 See Karaim Digital Archive https://jazyszlar.karaimi.org/ (1. August 2019). 
means that while there was an interest in topics concerning Jewish themes among Polish authors (essentially a question of representation), texts by authors of Jewish belonging written in other languages were only rarely being translated into Polish and thus were not being read (a question of distribution, access, and impact). Inside and outside of Poland, Jewish writers translated many works of Polish literature into other languages (Löw 2000). For example, the political text The Books of the Polish People and of the Polish Pilgrimage (1832) by Polish national Romantic poet Adam Mickiewicz was translated into Hebrew immediately after it was published. Therefore, the phenomenon of Polish Jewish literature has to be extended to include the often asymmetrical aspect of translation and reception between multiple languages.

Thirdly, when studying Polish Jewish literature, we also have to focus on the metaphorical phenomenon, termed today as the forgotten continent: Polish Jewish literature should also be thought of in terms of its broader comparative context. Jewish communities played a key role in neighboring countries outside of Poland. Small towns with large Jewish populations called shtetls were located mainly in Poland, but also in Lithuania, Belarus, Ukraine, Slovakia, the Czech Republic, Romania, and Hungary. It was almost as if these lands formed another continent that completely vanished during the Second World War - a borderland between East and West, an eastern province of Europe that shaped a similar or comparable literary experience that reverberated in literatures of different languages.

Fourthly, there is the challenge of the geographical spaces where the literature in question was created: Polish Jewish literature does not necessarily have to be written in Poland or in the territories that historically belonged to it. For a long time, between 1795 and 1918, Poland did not exist as an independent state. Numerous Jewish authors migrated during that time, and especially after the Second World War, and later after March events in 1968. Among those who survived, some writers began to publish all over the world: in France, Israel, in the U.S. or in Latin America. For example, one of the most important places of Polish Jewish culture was Buenos Aires, where, for example, Mark Turkow, a famous actor of the Yiddish theatre and cinema in Warsaw in the 1920s, edited a book series Dos pojlische jidntum (The Polish Jewry). Between 1946 and 1966, he published over 175 books; this would not have been possible in communist Poland where the Polish Jewish past had been silenced and repressed for decades. Thus, when reflecting on Polish Jewish literature, we have to acknowledge a diversity of languages, literary genres, and places of writing and publishing - and, of course, the incredible void after 1945. Therefore, our research field should also include the literary and artistic narratives operating between different cultures and imaginaries that search for a new language to express this emptiness. 


\section{Research: the case of Wtadystaw Panas}

The best-known platform for the exchange of ideas in studies on Polish Jewry is the POLIN journal that has been published since 1986 under the general editorship of Professor Antony Polonsky of Brandeis University. Its establishment coincides with a certain general tendency: the trilingual Jewish culture of Poland was largely ignored until after the end of communism. One of the recent volumes (28/2016, eds. Adamczyk-Garbowska, Prokop-Janiec, Polonsky, Żurek) is devoted to Jewish writing in Poland. It is fitting that the more than five-hundred-page volume opens with Władysław Panas's essay The Writing and the Wound first published in 1987.

A well-known literary scholar and professor of the Catholic University of Lublin, Panas was one of the pioneers of research on Polish Jewish literature, authoring books on semiotics, modernist poetry and prose, and Jewish motifs in Polish literature, with a special focus on Bruno Schulz. His monograph Księga Blasku: Traktat o kabale w prozie Brunona Schulza (The Book of the Splendor: The Treatise about the Kabbalah in the Prose of Bruno Schulz, 1997) deals with the traces of Jewish mystical thought, especially of the Lurianic Kabbalah, in Schulz's writings and was seen as a breakthrough for Schulzology. Incidentally, the topic of Schulz, Judaism, and Jewish mysticism is intensely studied, even though Schulz never explicitly thematized Jewish issues. For example, synagogues are never mentioned in his short stories, but there are some allusions to more general Jewish imagery, traditions, and motifs. Recently, a little 'discovery' has electrified Schulz-specialists all over the world: a forgotten essay by Schulz for a newspaper in 1937 on the illustrator and printmaker Ephraim Moses Lilien has been found and reprinted. Reflecting on his own works in this essay, Schulz wrote about Lilien as a Jewish artist and used the word Zionism for the first time (Schulz 2015).

Panas's essay The Writing and the Wound tries to define Polish Jewish literature by beginning with the Polish word for the graphic sign known as a 'hyphen': literatura polsko-żydowska. He makes a phenomenological and deconstructivist interpretation of this sign, which is written but cannot be heard while speaking - it unites and separates at once. This ambivalence of presence and absence symbolizes for him the voiceless trace of the wound and opens "a field of archetypical, essential gestures and meanings which dramatically pose the problem of Identity and Difference, of the Same One and the Other, the Whole and the Part" (18).

Panas states that in the 1930s in Polish literature we can observe the birth or "a full literary articulation of Jewish subjectivity" (22). For a long period, Jewish 
protagonists could appear in literary discourse, for example in Julian Ursyn Niemcewicz's novel Lejbe and Siora (1821). There were some Polish authors of Jewish descent like Julian Klaczko or Wilhelm Feldman who wrote explicitly about Jewish issues, but in accordance with the dominant style of Polish literature - from the perspective of a Jew as an object described from outside. According to Panas, the situation changed in 1931 with the publication of Maurycy Szymel's poetic debut Powrót do domu (Coming Back Home, see Szymel 2013). Panas emphasizes that the Jewish lyrical subject speaks to its readers for the first time as a Jew in Szymel's poems; Panas further sees in this Jewish speaking subject an archetype of the figure of the Other and Otherness, a symbol of some elemental experiences that could be split between the categories of "Ours and the Alien, the Native and the Foreigner, Sameness and Otherness, Identity and Difference" (22).

Panas distinguishes among various ways that Polish Jewish poetry expresses this difference that repeatedly proves to be an open wound in the writers' poetical belonging. The first tendency is that a Jewish lyrical speaker appears as the Other. To illustrate this, he quotes a line from a poem by Maurycy Schlanger, where he refers to himself as "a Polish poet, in Hebrew mute" (23). In this case, Jewish lyrical speakers describe a situation of exile, perceiving themselves as orphans or abandoned persons whose place is elsewhere. In such imagery, we encounter many dichotomies such as "here/there" or "Polish/Hebrew" or even elegies about the Hebrew language. Jewish lyrical speakers increase their speechlessness by speaking in Polish and express their longing for an absent world that cannot be reached. Such lyrical utterances reveal the complex belonging of these subjects as a wound that can be healed only by writing and script. Panas finds this mode of expression in the poetry of Maurycy Schlanger and Maurycy Szymel. The second tendency distinguished by Panas can be summarized with a verse by Włodzimierz Słobodnik: "I’m a son of Masovia, a grandson of ancient Judea” (25). The Jewish lyrical speaker understood as the Other wants to proclaim its otherness, but from the inside and as part of a bigger community.

The editors of the above mentioned POLIN volume observe in the introduction that Panas presents "the concept of Polish Jewish literature as a separate world (obieg) and offers a reading which treats as its basic distinguishing characteristic the attempt to record the experience of Jewish otherness / difference / estrangement" (10). According to Panas, Polish Jewish literature has to be understood "as a means of communication between Polish-speaking Jews. The key role in its functioning is played by its Polish Jewish readers" (10), the majority of whom disappeared after the Holocaust. Therefore, in Panas's understanding, Polish Jewish literature is limited to the interwar years and connected with 
some poets, prose writers, essayists, translators, and critics, as well as titles of newspapers and magazines from this period (19-20).

In the context of Polish Jewish literature, the most interesting aspects are the case studies of particular writers and the question of how they imagine their belonging. Reflecting on this complex matter, Panas shows that the accompanying literary discourse should deal with ethics and politics, especially regarding relationships among strangers who live close by but nevertheless remain unintelligible to one another. Consequently, the language he uses to grasp these very fragile phenomena is inspired by the philosophy of Edmond Jabès, Emmanuel Levinas, and Jacques Derrida.

Panas extends this thought in his other essay The Eye of the Tzaddik (1999), where he demonstrates the process of creating a myth, a mythology of a place that was left empty and forgotten after the Holocaust - the Jewish district in Lublin, a town in the eastern part of Poland. Instead of repeating familiar historical patterns, Panas chooses a widely unknown figure and thoroughly and patiently develops a story of Lublin Hasid Jacob Isaac Horowitz also known as "the Seer of Lublin" (1745-1815), who was largely responsible for putting the city on the map of the Hasidic movement. Panas's essay can be read as a Kaddish for the destroyed Jewish district, its inhabitants, and their literature. He looks for the place where the house of the tzaddik could have stood and tries to reconstruct it according to symbolic traces found in maps, poems, and artifacts such as a matzevah. Panas reads them as self-referential cultural texts that can be projected into this space and are also able to shape and arrange it so that the space is no longer a subject of description but a form in the process of eternal becoming.

The essay, however, can also be read as a text neither about the tzaddik nor about Lublin. History and geography are rather literary constructions that the essay ironically plays with. The tzaddik and the city have only an exemplary function in the essay, providing an impulse to introduce broader topics on how to reflect and write about the Polish Jewish past. The essay consists of ten parts, named after the letters of the Hebrew alphabet, from Aleph to Jod, but the allusions to Jewish mysticism are not the only field of reference for Panas. Placing the essay in the context of urban and memory studies as well as the theory and criticism of humanities in the sense of the German term Wissenschaftstheorie und -kritik can shed new light on it and explain the diversity of theories and disciplines that Panas combines. He uses categories from various research fields including semiotics, hermeneutics, geopoetics, philosophy of history, and phenomenology. Implicit and explicit references to the writings by Martin Buber, Mircea Eliade, Carl Gustav Jung, Maurice Halbwachs, Emmanuel Levinas, Yuri Lotman, Maurice Merleau-Ponty, Pierre Nora, and Gershom Scholem appear throughout Panas's essay. 
The Eye of the Tzaddik teems with intertextual allusions and can also be read as a literary piece: it resembles, for example, the short stories by Jorge Luis Borges. The intertextuality and metafictionality, autothematism and meta-commentaries, the interruption of narrative linearity initiated by the division of the essay according to the Hebrew alphabet, and the questioning of logical-rational reasoning constitute the special poetics of the text. Panas emphasizes how academic language and the language of theory is embedded in various discourses (religious, literary, philosophical, public) and points out that there is no axiologically 'neutral' way to reflect on historical facts. Therefore, he creates a complex narrative in which several languages from different registers flow together: poems, city maps, Hasidic stories, philosophical treatises, inscriptions on the matzevah, etc. Thus, the essay gets very close to the object of its description.

Panas seems to agree with Derrida that any language about a phenomenon “cannot be excluded from its object" (Derrida 1982, 90) and that the culture and text analysis requires the use of "the parodying heterogeneity of the style, the styles" (Derrida 1979, 99). It is only thanks to this diversity that the text avoids the reduction of the described phenomenon to an object of unambiguous definitions; leaves space free for undecidability and further interpretations; and distances itself from the hermeneutic project "which postulates a true sense of the text" (Derrida 1979, 107). The radical anarchy and heterogeneity of Panas's text, according to his writing style and methodology, can be understood as an ironic play with conventions and a theoretical proposal on how to reflect Polish Jewish history and literature.

The awareness in the essay of the relativity and constructability of history and its negotiable character go hand in hand with an emphasis on the power of storytelling. This is why Panas mentions the Hasidic story that he quotes after Scholem (Scholem 1993, 384), who in turn tells it after Agnon. The tale is about the Hasidim worrying how to face difficult tasks if their Master is gone and they do not have access to some parts of the ritual:

\footnotetext{
“We can no longer light the fire, nor do we know the right prayer; we even don't know where the place in the forest is located, but we can always tell the story about how everything happened." And the tzaddik's tale was just as effective as the deeds of those who came before him. (Panas 2015, 70).
}

A quotation in a quotation - a story in a story that says that when all is lost, the narrative about absence can work wonders. Again, a self-referential moment in the essay emphasizes that a narrative always postulates participation and interaction. The essay is not a closed product; the narrative functions only by retell- 
ing. Panas proposes a different view on the theory, which can be understood as a challenge to reality, as participation, taking action and intervening in the world inseparably connected with it or constituting its symbolic universes as well as a performative answer to it/them. This means a different approach to acting, located somewhere between theory and practice, underlying the immersion of the writer and researcher in the world or topic of research, and the readiness on both sides to transform each other.

This is an exemplary approach which shows how writing about Polish Jewish literature requires and fosters the invention of an extraordinary theoretical and self-critical language capable of reaching and grasping the complexity of this phenomenon. It would have to be creative and heterogeneous, engaging different conceptual frameworks that belong not only to literary theory, but also other disciplines in the humanities. Panas consistently crosses disciplinary borders and seeks new sources of inspiration in philosophy, aesthetics, cultural studies, theology, and Jewish mysticism. Transforming his programmatic principle into teaching, one could imagine including a variety of texts on the reading list: a diverse combination of primary and secondary literature, different genres from different epochs that on the one hand illustrate some of the challenges of teaching and thinking about Polish Jewish literature and, on the other hand, develop the student's theoretical capacities.

\section{A teaching example}

A syllabus for a seminar in Polish Jewish literatures has to offer a broad array of appropriate texts. In choosing the texts for my seminars, I emphasize the multilingual and multicultural dimensions of this literary phenomenon. A comparative perspective necessarily includes diverse literary genres and styles, as well as texts from different periods. Although the diachronic juxtaposition of oeuvres requires extra time to contextualize them, I see it as an opportunity to review key concepts of the history of literature and literary theory. I also tend to focus on a specific geographical context - on Lublin and the Lublin region, i.e. on texts that were written in or about this area. The aim here is to stress that Polish Jewish literatures should be associated with the area where they were produced rather than attributed to one language. This also enables me to introduce theoretical categories such as the spatial turn and geopoetics and to point to a region that is not as strongly present in literary and cultural studies as, for example, Bukovina, Galicia (Galizien), and the Hutsul region (Hutsulshchina).

The title of the seminar I taught in the winter term 2016/2017 at Potsdam University was: Literary Topographies and Cultural Entanglements: The City of Lublin 
and the Lublin Area in Jewish and Non-Jewish Literatures. The uniqueness of the region consists of the fact that the city was a melting pot - a cultural space that cannot be mapped in terms of nation states because it was historically multi-ethnic and multicultural, strongly influenced by its Jewish population. The area became prominent thanks to the works of Isaac Bashevis Singer, the 1978 Nobel Prize winner, the first and to date only Yiddish writer to receive this honor. In his novel The Magician of Lublin, the town of Lublin became the symbol of the lost pre-World War II world of Polish Jews. The global audience has also had the opportunity to get to know this region through Martin Buber's Tales of the Hasidim.

In class, we analyzed literary texts written before and after the Holocaust that depict the cultural and historical contexts of the region. We focused on aspects such as the Hasidic tradition of storytelling and its echoes in modern times; the literary avant-garde and the historical experiences of Eastern Europe; and representations of the Holocaust in poetry and prose.

We began the seminar with stories about the Jewish town of Lublin. We compared the reportage of his journey in Poland in the 1920s by German novelist Alfred Döblin (2016, 147-168) with two historical narratives: excerpts from Die Judenstadt von Lublin (1919), a monograph about this district which was written in German, published in Berlin, and authored by Majer Bałaban (often regarded as the founder of contemporary Jewish historiography in Poland); and a chapter from Jewish Lublin: A Cultural Monograph (2009) by contemporary Mexican scholar Adina Cimet (2009). We debated on how the narrator in Döblin's text - an assimilated, well-educated Jewish writer from the German metropolis - perceived Lublin and how he represented it. We compared the narrative perspective of his travel report with the metaphoric language used by historians to describe relationships between the Polish and Jewish parts of the town.

The next part of the seminar program was a discussion of the figure of the abovementioned Hasid Jacob Isaac Horowitz, the Seer of Lublin - a rabbi, tzaddik, and leader of the early Hasidic movement who lived in the Jewish district of the town in the late eighteenth and early nineteenth centuries. He is not only a historical but also a literary figure: there is much hagiographic literature in Yiddish about tzaddik Horowitz in addition to tales and legends about the miracles he performed. ${ }^{2}$ He is also present in the stories by Martin Buber (1957, 7-10) and Jiří Langer (1976, 179-198).

2 The collection of hagiographic texts about the Seer of Lublin was translated into Polish and published as Księga cudów Widzącego (Doktór et al. 2015). 
In our course, the Seer of Lublin functioned as a bridge - a transition to the subject of Hasidism and the Hasidic tradition of storytelling in modern literature. Several classes were devoted to the works of Yiddish writers of different generations such as Isaac Leib Peretz and Isaac Bashevis Singer. Both are associated with this region and its shtetls: Peretz was born in Zamość, while Singer was connected with Biłgoraj through his mother's family (see Adamczyk-Garbowska/ Wróblewski 2005). The Lublin region was often an inspiration for Singer's works - not only Lublin itself, which is explicitly present in his two novels Satan in Goray (1935) and The Magician of Lublin (1960), but also the nearby cities of Chełm and Biała Podlaska, which appear in The Fools of Chelm and Their History (1973) and The Family Moskat (1950), respectively. We analyzed the representation of time and space in selected short stories by both authors and discussed common points among their styles, supplementing our knowledge by studying secondary literature on the topic (e.g. Roskies/Roskies 1975, Roskies 1995, Ronen/Molisak 2017).

An examination of Singer's works directed our attention to another Nobel Prize laureate: S. Y. Agnon, who in 1966 became the first Hebrew-speaking winner of this award. Although the plot of his posthumously published novel In Mr. Lublin's Store (1974) is set in Leipzig during the First World War, it nevertheless registers the significance of the subject of Polish Jewish migration.

After this, we turned to poetry: on the basis of selected poems by Arnold Słucki, we studied how the lyrical speaker addresses the theme of Polish Jewish belonging. Słucki, born in 1920 as Aron Kreiner in the town of Tyszowce in the province of Lublin, began his poetic career in Yiddish. After the war, he switched to Polish. After the anti-Semitic violence unleashed by the Polish government in 1968, he left Poland and died in West Berlin in 1972. After his death, the first extensive anthology in Polish edited by him, containing translations from Yiddish, including his own, was posthumously published under the title Antologia poezji żydowskiej (Anthology of Jewish Poetry). When analyzing the poems, we focused the motifs of dilemma, of seeking poetic language, and the loss of the world of shtetls and one's roots.

The theme of loss was also present when we discussed the poems by another poet, Józef Czechowicz, an important representative of the Polish poetic avantgarde in the interwar period. He was born in Lublin where he also died a tragic death during an air raid in the first days of the Second World War. He devoted many texts to his hometown, such as a volume of verse Stare kamienie (Old Stones) and the "Poemat o mieście Lublinie" (“A Poem About Lublin”), which is also available in English translation (2008, 5-18). Czechowicz is often termed a catastrophic poet - the feelings of a coming tragedy, uncertainty, and anxiety are strongly present in his poems. Some of them have been recently reedited 
by Iwona Chmielewska in form of a picture book that develops its own intermedial poetics of the loss (2016).

When we dealt with the Holocaust, we focused on Majdanek, a concentration camp named after the Lublin district of Majdan Tatarski. We used earlier testimonies about the camp: a piece of reportage by a camp survivor, Mordechai Strigler, writer and journalist writing in Yiddish (1947, German translation 2016), and compared it to the report of the Polish-Soviet "Extraordinary Commission to Investigate German Crimes Committed in the Majdanek Extermination Camp in Lublin" (Moscow 1944). We considered the differences in literary means and tropes, stylistic figures, and narrative constructions that exist among reportage, nonfiction, and testimony.

We discussed literary representations of the Holocaust both in poetry and in prose. We read the poems by Jacob Glatstein, a Yiddish-writing poet living in Lublin, who immigrated to New York in 1914. In his works, Lublin became a symbol of the destruction of the pre-war world of Polish Jews. We also discussed prose writings by Anna Langfus, Lublin-born writer. During the war, she stayed in the Lublin Ghetto; after the war, she settled in France, where she began her writing career in French. Her novels, such as Le Sel et le Soufre (1960, English translation The Whole Land Brimstone) and the prestigious Prix Goncourt-awarded Les Bagages de sable (1962, The Lost Shore), are some of the first to represent the Holocaust from the perspective of a woman's experience. To highlight Langfus's laconic and matter-of-fact style, we compared her texts with excerpts from the famous novel La Disparition (1969, A Void) by Georges Perec - French essayist, writer, and filmmaker, whose father and grandparents came from Lubartów near Lublin and who was born in Paris in 1936 after his family emigrated to France in the 1920s. We ended the seminar with a reflection on literature written after the Holocaust and on the phenomenon of postmemory. We also included non-Jewish writings dedicated to the memory of perpetrators. In this context, we analyzed Jonathan Littell's controversial bestseller Les Bienveillantes (2006, The Kindly Ones). More than one hundred pages of this novel - written from the perspective of an SS officer, a mass murder recounting his unscrupulous crimes - take place in Lublin and its surroundings.

As the language competencies varied within the student group, we relied mainly on translations, which was a separate subject we tried to critically discuss by referring to theories of translation. The reading list was compiled so as to make all literary texts available in English and/or German translations, with the originals available to those interested. Although the city of Lublin and its surroundings served only as a case study for becoming acquainted with broader issues of Polish Jewish literature, it was very important that the students should not only view these specific localities as literary fictions, but also have the op- 
portunity to physically experience them. Thanks to the support provided by the German Academic Exchange Service (DAAD), I was able to organize a study visit to Lublin for the students.

I complemented the extensive collection of texts with multimedia presentations. The students were encouraged to study individually with material available on the Internet. Appended below is a list of several links to databases on Polish Jewish literature, which turned out to be useful in teaching:

- The "Grodzka Gate - NN Theatre” Centre and its Digital Library: http:// teatrnn.pl/en/

- Project Shtetl Routes - A Travel through the Forgotten Continent by Shtetl Routes of the Polish, Belorussian and Ukrainian Borderland: http://shtetl routes.eu/en/

- The Jewish Historical Institute in Warsaw and its library: http://www.jhi.pl/ en/zasoby; https://cbj.jhi.pl/

- POLIN Museum of the History of Polish Jews: https://www.polin.pl/en/re search-and-publications

- Journal Polin: Studies in Polish Jewry: https://www.liverpooluniversitypress. co.uk/series/series-12813/

- Encyclopedia Judaica: Polish Literature: https://www.jewishvirtuallibrary. org/polish-literature

- The YIVO Encyclopedia of Jews in Eastern Europe: http://www.yivoencyclo pedia.org/article.aspx/Polish_Literature

- Collection of digitalized books in Yiddish: https://polona.pl/collections/in stitutions/1/literatura-jidysz,NDI0ODQ1MDAyNzc3NDcyMzY2MA/?sort=score $\%$ 20desc

The focus on geopoetics, on geographical territory as a binding point for heterogeneous texts, has proven productive in developing courses on Polish Jewish literatures. My wishes and expectations with regard to teaching in this field is to demonstrate that our object of study is a multilingual and multicultural phenomenon with a long history and continuity up to and including the present moment.

\section{Bibliography}

Adamczyk-Garbowska, Monika. Odcienie tożsamości: literature żydowska jako zjawisko wielojęzyczne. Lublin: UMCS, 2004.

Adamczyk-Garbowska, Monika and Bogusław Wróblewski (eds.). Biłgoraj czyli Raj: rodzina Singerów i świat, którego już nie ma. Lublin: UMCS, 2005. 
Adamczyk-Garbowska, Monika and Eugenia Prokop-Janiec. "Introduction.” Polin: Studies in Polish Jewry 28 (2016). Eds. Monika Adamczyk-Garbowska, Eugenia Prokop-Janiec, Antony Polonsky, Stawomir Jacek Żurek. 1-14.

Agnon, Shmuel Yosef. In Mr. Lublin's Store. Trans. Glenda Abramson. New York: Toby Press LLC, 2016.

Agnon, Shmuel Yosef and Ahron Eliasberg (eds.). Das Buch von den polnischen Juden. Berlin: üdischer Verlag, 1916. https://sammlungen.ub.uni-frankfurt.de/freimann/content/ti tleinfo/4666820 (1 August 2019).

Bałaban, Majer. Die Judenstadt von Lublin. Berlin: Jüdischer Verlag, 1919. https://sammlun gen.ub.uni-frankfurt.de/freimann/content/search/729867?query=balaban (1 August 2019).

Ben-Zvi, Hava (ed.). Portraits in Literature: The Jews of Poland. An Anthology. London, Portland: Vallentine Mitchell, 2011.

Buber, Martin. Gog und Magog: eine Chronik. Frankfurt am Main: Fischer, 1957.

Cimet, Adina. Jewish Lublin. A Cultural Monograph. Lublin: UMCS, 2009.

Czechowicz, Józef (poems), Iwona Chmielewska (illustrations), and Abram Zylberberg (photographies). Dopóki niebo nie płacze. Lublin: "Ośrodek Brama Grodzka -Teatr NN," 2016.

Czechowicz, Józef. A Poem about Lublin. Trans. Małgorzata Sady and George Hyde, Lublin: “Ośrodek Brama Grodzka - Teatr NN”, 2008. http://pretekstyliterackie.art.pl/historia/cze chowicz\%20angielski.pdf (1 August 2019).

Derrida, Jacques. "Of an Apocalyptic Tone Recently Adopted in Philosophy.” Trans. John P. Leavey Jr. Semeia 23 (1982): 63-97.

Derrida, Jacques. Spurs: Nietzsche's Styles. Trans. Barbara Harlow. Chicago and London: University of Chicago Press, 1979.

Döblin, Alfred. Reise in Polen. Ed. Marion Brandt. Frankfurt am Main: Fischer, 2016.

Doktór, Jan, Agnieszka Żótkiewska, and Nirit Neeman (eds.). Księga cudów Widzącego. Trans. Agnieszka Żótkiewska. Lublin: Ośrodek “Brama Grodzka - Teatr NN,” 2015.

Glatstein, Jakob. I Keep Recalling: The Holocaust Poems of Jacob Glatstein. Trans. Barnett Zumoff. Hoboken and New York: Ktav Publ. House, 1992.

Grözinger, Elvira. “Das verlorene Paradies. Zu Arnold Stuckis Dichtung.” Suche die Meinung. Karl Dedecius, dem Übersetzer und Mittler zum 65. Geburtstag. Eds. Elvira Grözinger and Andreas Lawaty. Wiesbaden: Harrassowitz, 1986. 320-339.

Hutchens, Jack J. B. “Julian Stryjkowski: Polish, Jewish, queer.” Canadian Slavonic Papers / Revue Canadienne des Slavistes 61.1 (2019): 57-80.

Kołodziejska, Zuzanna and Maria Antosik-Piela (eds.). Literatura polsko-żydowska 1861-1918: studia i szkice. Kraków: Wyd. UJ, 2018.

Kołodziejska, Zuzanna and Maria Antosik-Piela (eds.). Literatura polsko-żydowska 1861-1918: antologia. Kraków: Wyd. UJ, 2017.

Langer, Jiři. Nine Gates to the Chassidic Mysteries. Trans. Stephen Jolly. New York: Behrman House, 1976.

Langfus, Anna. The Lost Shore. Trans. Peter Wiles. New York: Pantheon Books, 1964.

Langfus, Anna. The Whole Land Brimstone. Trans. Peter Wiles. New York: Pantheon Books, 1962.

Leociak, Jacek. “Recenzja (Eugenia Prokop-Janiec, Józef Wróbel, Natan Gross)” Pamiętnik Literacki 3. 86 (1995): 144-153. 
Littell, Jonathan. The Kindly Ones. Trans. Charlotte Mandell. New York: Harper, 2009.

Löw, Ryszard. "Literatura polska w przekładach hebrajskich” Archiwum Emigracji: Studia, Szkice, Dokumenty 3 (2000): 93-101.

Maciejko, Pawet. The Mixed Multitude: Jacob Frank and the Frankist Movement, 1755-1816. Philadelphia, PA: University of Pennsylvania Press, 2011.

Molisak, Alina and Mieczystaw Dąbrowski (eds.). Pisarze polsko-żydowscy XX wieku: przybliżenia. Warszawa: Elipsa, 2006.

Molisak, Alina and Shoshana Ronen (eds.). The Trilingual Literature of Polish Jews from Different Perspectives. Cambridge: Cambridge Scholars Publishing, 2017.

Molisak, Alina and Zuzanna Kołodziejska (eds.). Żydowski Polak, polski Żyd: problem tożsamości w literaturze polsko-żydowskiej. Warszawa: Elipsa, 2011.

Norich, Anita. "Jewish Literatures and Feminist Criticism: An Introduction to Gender and Text." Gender and Text in Modern Hebrew and Yiddish Literatures. Eds. Naomi B. Sokoloff, Anne Lapidus Lerner, and Anita Norich. New York: Jewish Theological Seminary of America, distributed by Harvard University Press, 1992.

Panas, Władystaw. "The Writing and the Wound: On Polish-Jewish Literature." Trans. Christopher Garbowski. Polin: Studies in Polish Jewry 28 (2016). Eds. Monika Adamczyk-Garbowska, Eugenia Prokop-Janiec, Antony Polonsky, Stawomir Jacek Żurek. $17-29$.

Panas, Władysław. Oko cadyka. The Eye of the Tzaddik. Trans. Marcin Garbowski. Lublin: Warsztaty Kultury, 2015.

Panas, Władysław. Pismo i rana: szkice o problematyce żydowskiej w literaturze polskiej. Lublin: Dabar, 1996.

Perec, Georges. A Void. Trans. Gilbert Adair. Boston: D.R. Godine, 2005.

Polonsky, Antony and Monika Adamczyk-Garbowska (eds.). Contemporary Jewish Writing in Poland: An Anthology. Lincoln: University of Nebraska Press, 2001.

Prokop-Janiec, Eugenia, and Sławomir Jacek Żurek (eds.). Literatura polsko-żydowska - studia i szkice. Kraków: Księgarnia Akademicka, 2011.

Prokop-Janiec, Eugenia. Living in Languages: Jewish Multilingualism as Reflected in the Polish and Polish-Jewish Literature of the 20th Century. Kraków: Księgarnia Akademicka, 2002.

Prokop-Janiec, Eugenia. Polish-Jewish Literature in the Interwar Years. Trans. Abe Shenitzer. Syracuse, NY: Syracuse University Press, 2003.

Prokop-Janiec, Eugenia. Pogranicze polsko-żydowskie. Topografie i teksty. Kraków: Wydawnictwo UJ, 2013.

Roskies, David G. A Bridge of Longing: The Lost Art of Yiddish Storytelling. Cambridge, MA: Harvard University Press, 1995.

Roskies, Diane K. and David G. Roskies. The Shtetl Book: An Introduction To East European Jewish Life And Lore. New York: Ktav Publishing House, 1975.

Scholem, Gershom. Die jüdische Mystik in ihren Hauptströmungen. Frankfurt am Main: Suhrkamp, 1993.

Schulz, Bruno. “E. M. Lilien.” Schulz/Forum 6 (2015): 82-96. https://terytoria.com.pl/mod ules/nxproduct/images/1101/fragment-schulz-forum-6-strony_1496392929.pdf (1 August 2019). 
Segałowicz, Zusman. Tłomackie 13: (z unicestwionej przeszłości): wspomnienia o Żydowskim Zwiq̨zku Literatów i Dziennikarzy w Polsce (1919-1939). Trans. Michał Friedman. Warszawa: Wydawnictwo Dolnośląskie, 2001.

Strigler, Mordecai. Majdanek: verloschene Lichte. Ein früher Zeitzeugenbericht vom Todeslager. Trans. Sigrid Beisel. Springe: zu Klampen, 2016.

Szymel, Maurycy (Mosze). The Shy Hand of a Jew. Trans. Aniela and Jerzy Gegorek. Merrick, NY: Cross-Cultural Communications, 2013.

Żurek, Stawomir Jacek. "As One Kabbalist to Another... On Arnold Słucki's Mystical Visions in the Poem 'Bruno Schulz'." (Un)masking Bruno Schulz: New Combinations, Further Fragmentations, Ultimate Reintegrations. Eds. Dieter de Bruyn and Kris Van Heuckelom. Amsterdam: Rodopi, 2009. 67-82.

Żurek, Stawomir Jacek. From the Borderland: Essays on Polish-Jewish Literature. Trans. Thomas Anessi. Lublin: KUL, 2008. 
